\title{
Temperature and ph effects on the relative sweetness of suprathreshold mixtures of dextrose fructose'
}

\author{
HERBERT STONE, ${ }^{2}$ SHIRLEY OLIVER AND JOAN KLOEHN \\ LIFE SCIENCES DIVISION, STANFORD RESEARCH INSTITUTE
}

Increasing the temperature from $5 \mathrm{deg}$ to $50 \mathrm{deg} C$ did not significantly alter the relative sweetness of aqueous solutions of dextrose, fructose, and their combination, as measured by the method of magnitude estimation, with a panel of 12 experienced Ss. Reducing $p H$ from 5.8 to 2.7 caused about a $50 \%$ reduction in relative sweetness for all stimuli tested. The slopes of these lines tended to decrease slightly, whereas the $Y$-intercept values showed the greatest change. In all experiments the slopes of the lines were reasonably stable, averaging 1.40 vs 1.3 reported by Stevens (1961) for sucrose. The results of these experiments are discussed in relation to previously reported data on taste interactions.

In a study reported earlier (Stone \& Oliver, 1968), it was observed that mixtures of selected sugars were significantly sweeter than the simple addition of their individual sweetness as measured by the method of magnitude estimation. Of all the sugars and sugar mixture combinations studied, the largest effect, about $35 \%$, was noted with dextrose-fructuse mix tures. It was of interest to investigate to what extent such factors as temperature and $\mathrm{pH}$ influenced the estimates of relative sweetness intensity for this sugar mixture. Sato (1967), in a recent review on the effect of temperature on gustatory response, summarized the human evidence as somewhat contradictory, depending on the stimuli (sweet, sour, salty, or bitter), and the experimental temperatures. In experiments with mammals other than man, Sato reported that when the tongue was preadapted to the experimental temperature the response to various taste stimuli was greatest when the stimulus was at the temperature of the tongue (approximately $30 \mathrm{deg}$ ). This response usually decreased in magnitude at either extreme ( $10 \mathrm{deg}$ or $50 \mathrm{deg} \mathrm{C}$ ), although he cautioned against simple extrapolation from one animal species to another and from one taste quality to another. In man, the situation appears to be no less confusing. Pfaffmann (1959) summarized much of the work by pointing out that temperature effects were variable, citing Goudrian (1930) as reporting apparent taste intensity of sugar solutions increasing with temperatures changing from $10 \mathrm{deg}$ to $40 \mathrm{deg} C$. Tsuzuki and Yamazaki (1953) reported the relative sweetness intensity of fructose decreased going from $5 \mathrm{deg}$ to $60 \mathrm{deg} \mathrm{C}$.

The effect of $\mathrm{pH}$ on the relative sweetness of sugars is generally conceded to be one of depression. In a series of studies with acetic, citric, lactic, and tartaric acids, Pangborn (1961, 1965) found all four depressed the sweetness intensity of the four test sugars (sucrose, fructose, glucose, lactose).

Since previous investigators had employed single sugars and not mixtures, we felt it desirable to report our results using suprathreshold mixtures of dextrose-fructose solutions.

\section{Subjects}

\section{METHOD}

Twelve persons, all of whom had prior experience with taste testing, were used as the panel. Each $S$ participated in every experiment and missed sessions were made up as soon as possible. The Ss were tested individually approximately the same time of day throughout the experiment.

\section{Stimuli}

This study was divided into two parts; the first part considered the effect of temperature and the second the effect of $\mathrm{pH}$.

The test stimuli for both experiments were dextrose (highest purity, Corn Products Company) and fructose (Mann Assayed, CP, S1290). The $\mathrm{pH}$ was adjusted with citric acid. All compounds had a purity in excess of $99 \%$.

Glass-distilled, charcoal-filtered water was used to prepare the solutions and was available to Ss for rinsing purposes. All solutions were prepared approximately $24 \mathrm{~h}$ before testing and were discarded after $48 \mathrm{~h}$. Fresh solutions were prepared for make-up tests. Distilled water also was prepared fresh every three days.

Each solution was prepared on a wt/vol basis. All solutions were stored and tested at $21 \mathrm{deg} \pm 2 \mathrm{deg} C$ except for those used in the temperature experiment. For each single-sugar and sugar-mixture experiment, a series of four (and sometimes five) solutions (usually $\log _{2}$ ) were prepared.

For the temperature experiments care was taken to minimize moisture loss and temperature variations. Stock solutions were maintained at the elevated temperature by means of a covered, heated tray and removed only for the time required to pour out a sample. For the lower temperature we used a small cooling unit. To adjust $\mathrm{pH}$, we used citric acid in either crystalline or aqueous form, depending on the amounts required. Corrections were made for the dilution caused when water was used.

\section{Procedures}

The method of magnitude estimation was used to obtain the relative sweetness of the individual sugars and the sugar mixtures (Stevens, 1961). S was informed of the test procedure and that he would receive a reference of identified intensity (10). The reference always was $0.25-\mathrm{M}$ sucrose, although Ss were not informed of this fact. The reference was usually at the geometric mean of the series. The rationale for our procedure has been described elsewhere (Stone \& Oliver, 1968).

Initially the relative sweetness was established for the single sugars and then for the mixtures. The second sugar always was the fructose, added at two different concentrations $(0.0625$ and $0.125 \mathrm{M}$ ).

Test solutions were presented in a random sequence and each of the 12 Ss was tested five times at each concentration.

\section{Analysis}

Analysis of the data was accomplished making use of the "Psychofit" program (kindly provided by Professor Trygg Engen and Mr. Alan Kalikow, Brown University). Data input included individual responses and stimulus concentrations, and, where appropriate, reference estimations. Output included pooled geometric means for each stimulus, variance, standard deviations, medians, first and third quartile values, equations of the line through the geometric means, least-square line through the medians (for normalized and nonnormalized data), and Pearson $R$ and $R^{2}$. Other data also were available.

\section{RESULTS}

In the first experiment, increasing or decreasing the temperature did not significantly alter the relative sweetness of 
Table 1

Magnitude Estimates of the Relative Sweetness of Dextrose and Fructose and

Their Mixtures as a Function of Temperature ${ }^{\mathrm{a}}$

\begin{tabular}{|c|c|c|c|c|c|c|}
\hline & \multicolumn{6}{|c|}{ Sugar (Molar concentration) } \\
\hline & 0.0625 & 0.125 & 0.25 & 0.50 & 1.0 & 2.0 \\
\hline & & & Temperature & $f 5 \operatorname{deg} C( \pm 1$ & eg C) & \\
\hline \multirow[t]{2}{*}{ Dextrose } & - & 0.19 & 0.48 & 2.21 & 14.11 & 27.91 \\
\hline & - & $(0.06-0.6)$ & $(0.38-0.97)$ & $(1.4-2.9)$ & $(5.8-33.6)$ & $(13.455 .8)$ \\
\hline \multirow[t]{2}{*}{ Fructose } & 0.43 & 1.06 & 3.68 & 12.05 & 23.71 & - \\
\hline & $(0.18-1.0)$ & $(0.86-1.9)$ & $(2.6-4.9)$ & $(6.9-14.7)$ & $(14.9-25.7)$ & - \\
\hline \multirow[t]{2}{*}{ Dextrose $+0.0625-M$ Fructose } & - & 0.79 & 4.01 & 7.13 & 21.31 & - \\
\hline & - & $(0.4-1.6)$ & $(3.3-5.7)$ & $(5.4-9.2)$ & $(14.2-23.7)$ & - \\
\hline \multirow[t]{3}{*}{ Dextrose $+0.125-\mathrm{M}$ Fructose } & - & 1.55 & 3.01 & 10.07 & 19.43 & - \\
\hline & - & $(0.844 .8)$ & $(1.8-6.4)$ & $(8.6-13.1)$ & $(16.8-22.2)$ & - \\
\hline & \multicolumn{6}{|c|}{ At Temperature of $22 \operatorname{deg} C( \pm 2 \operatorname{deg} C)$} \\
\hline \multirow[t]{2}{*}{ Dextrose } & - & 0.44 & 1.07 & 4.29 & 15.73 & 32.53 \\
\hline & - & $(0.22-0.89)$ & $(0.88-1.7)$ & $(3.1-5.3)$ & $(8.4-21.1)$ & $(20.8-43.3)$ \\
\hline \multirow[t]{2}{*}{ Fructose } & 0.59 & 1.66 & 3.99 & 12.69 & 24.17 & - \\
\hline & $(0.7-1.5)$ & $(1.4-1.9)$ & $(2.9-4.3)$ & $(8.6-16.6)$ & $(17.4-30.8)$ & - \\
\hline \multirow[t]{2}{*}{ Dextrose $+0.0625-\mathrm{M}$ Fructose } & - & 1.33 & 2.65 & 7.46 & 22.09 & - \\
\hline & - & $(0.89-2.2)$ & $(2.2-3.0)$ & $(5.9-9.5)$ & $(14.8-32.2)$ & - \\
\hline \multirow[t]{3}{*}{ Dextrose $+0.125-\mathrm{M}$ Fructose } & - & 2.03 & 4.14 & 10.59 & 26.88 & - \\
\hline & - & $(1.4-2.7)$ & $(3.2-5.3)$ & $(8.9-12.0)$ & $(20.4-31.1)$ & - \\
\hline & \multicolumn{6}{|c|}{ At Temperature of $50 \operatorname{deg} C( \pm 5 \operatorname{deg} C)$} \\
\hline \multirow[t]{2}{*}{ Dextrose } & - & 0.70 & 1.69 & 5.56 & 16.65 & 29.12 \\
\hline & - & $(0.49-1.2)$ & $(1.3-2.1)$ & $(4.4-6.5)$ & $(12.1-19.2)$ & $(20.2-33.6)$ \\
\hline \multirow[t]{2}{*}{ Fructose } & 0.84 & 1.72 & 5.18 & 13.33 & 25.69 & - \\
\hline & $(0.75-1.5)$ & $(1.5-2.4)$ & $(3.8-6.1)$ & $(9.5-12.9)$ & $(17.4-27.2)$ & - \\
\hline \multirow[t]{2}{*}{ Dextrose $+0.0625-\mathrm{M}$ Fructose } & - & 1.50 & 3.01 & 9.95 & 21.42 & - \\
\hline & - & $(1.6-2.1)$ & $(2.4-4.3)$ & $(7.7-9.9)$ & $(14.8-26.6)$ & - \\
\hline \multirow[t]{2}{*}{ Dextrose $+0.125-\mathrm{M}$ Fructose } & - & 2.46 & 4.60 & 12.13 & 22.63 & - \\
\hline & - & $(2.1-3.5)$ & $(4.1-5.4)$ & $(9.5-13.9)$ & $(14.6-29.4)$ & - \\
\hline
\end{tabular}

$a$ In all experiments the reference, 0.25-M sucrose was designated as 10 and was served at room temperature $(22$ deg $C)$.

Each entry is the geometric mean of 60 responses. Entries in parenthesis are the first and third quartile values.

the single sugars or of the mixtures. These data are summarized in Tables 1 and 2. Although the relative sweetness intensity values were slightly greater at the higher temperature, these differences were not statistically significant.

Results of changing $\mathrm{pH}$ are summarized in Tables 3 and 4 . In these experiments, adjusting $\mathrm{pH}$ to 2.7 produced a not unexpected decrease in the relative sweetness. Changing the $\mathrm{pH}$ to 4.0 did not influence the relative sweetness.

It was of interest to find that the slopes of the lines in these experiments were consistent with our previously reported results using an entirely different panel (Stone \& Oliver, 1968). In the present study the average slope value was 1.40 vs 1.16 in that experiment. In general, we found that the slope values varied between Ss in an experiment, but were less variable between experiments for any one $S$.

\section{DISCUSSION}

The fact that no significant changes in relative sweetness occurred after changing the temperature was quite surprising in view of previously reported results. The two previously

Table 2

Summary Statistics-Slope Values, Variances, Standard Deviations, Y-Intercepts, and Correlation Coefficients (R) for the Temperature Experiments

\begin{tabular}{|c|c|c|c|c|c|}
\hline \multirow[b]{3}{*}{ Dextrose } & Slope & & & & $\mathbf{R}$ \\
\hline & \multicolumn{5}{|c|}{ At Temperature of $5 \operatorname{deg} C( \pm 1 \operatorname{deg} C)$} \\
\hline & 1.9318 & 1.1774 & 1.0851 & -0.0396 & 0.9603 \\
\hline Fructose & 1.5061 & 0.5988 & 0.7738 & 0.4438 & 0.9665 \\
\hline Dextrose $+0.0625-\mathrm{M}$ Fructose & 1.5076 & 0.5094 & 0.7137 & 0.3517 & 0.9680 \\
\hline \multirow[t]{2}{*}{ Dextrose + 0.125-M Fructose } & 1.2690 & 0.4350 & 0.6595 & 0.3130 & 0.9795 \\
\hline & \multicolumn{5}{|c|}{ At Temperature of $22 \operatorname{deg} C( \pm 2 \operatorname{deg} C)$} \\
\hline Dextrose & 1.6491 & 0.4576 & 0.6765 & 0.0935 & 0.9745 \\
\hline Fructose & 1.3675 & 0.4120 & 0.6418 & 0.4384 & 0.9684 \\
\hline Dextrose +0.0625 -MFructose & 1.3642 & 0.1977 & 0.4446 & 0.7183 & 0.9829 \\
\hline \multirow[t]{2}{*}{ Dextrose $+0.125-\mathrm{M}$ Fructose } & 1.2534 & 0.0995 & 0.3155 & 0.7881 & 0.9797 \\
\hline & \multicolumn{5}{|c|}{ At Temperature of $50 \operatorname{deg} C( \pm 5 \operatorname{deg} C)$} \\
\hline Dextrose & 1.4186 & 0.5060 & 0.7114 & 0.1240 & 0.9797 \\
\hline Fructose & 1.2820 & 0.6723 & 0.8199 & 0.4538 & 0.9821 \\
\hline Dextrose $+0.0625-\mathrm{M}$ Fructose & 1.3218 & 0.4319 & 0.6572 & 0.3431 & 0.9774 \\
\hline Dextrose $+0.125-M$ Fructose & 1.1000 & 0.2358 & 0.4856 & 0.3698 & 0.9830 \\
\hline
\end{tabular}


Table 3

Magnitude Estimates of the Relative Sweetness of Dextrose and Fructose and

Their Mixtures as a Function of $\mathrm{pH}^{\mathrm{a}}$

\begin{tabular}{|c|c|c|c|c|c|c|}
\hline \multirow{3}{*}{ Dextrose } & \multicolumn{6}{|c|}{ Sugar (Molar concentration) } \\
\hline & \multicolumn{6}{|c|}{ At $\mathrm{pH} 5.8$} \\
\hline & $\begin{array}{l}- \\
-\end{array}$ & $\begin{array}{l}0.44 \\
(0.22-0.89)\end{array}$ & $\begin{array}{l}1.07 \\
(0.88-1.7)\end{array}$ & $\begin{array}{l}4.29 \\
(3.1-5.3)\end{array}$ & $\begin{array}{l}15.73 \\
(8.4-21.1)\end{array}$ & $\begin{array}{l}32.53 \\
(20.8-43.3)\end{array}$ \\
\hline Fructose & $\begin{array}{c}0.59 \\
(0.7-1.5)\end{array}$ & $\begin{array}{l}1.68 \\
(1.4-1.9)\end{array}$ & $\begin{array}{l}3.99 \\
(2.9-4.3)\end{array}$ & $\begin{array}{l}12.69 \\
(8.6-16.6)\end{array}$ & $\begin{array}{l}24.17 \\
(17.4-30.8)\end{array}$ & - \\
\hline Dextrose $+0.0625-\mathrm{M}$ Fructose & $\begin{array}{l}- \\
-\end{array}$ & $\begin{array}{l}1.33 \\
(0.89-2.2)\end{array}$ & $\begin{array}{l}2.65 \\
(2.2-3.0)\end{array}$ & $\begin{array}{l}7.46 \\
(5.9-9.5)\end{array}$ & $\begin{array}{l}22.09 \\
(14.8-32.2)\end{array}$ & - \\
\hline \multirow[t]{2}{*}{ Dextrose $+0.125-M$ Fructose } & - & $\begin{array}{l}2.03 \\
(1.4-2.7)\end{array}$ & $\begin{array}{c}4.14 \\
(3.4-5.3)\end{array}$ & $\begin{array}{l}10.59 \\
(8.9-12.0)\end{array}$ & $\begin{array}{l}26.88 \\
(20.4-31.1)\end{array}$ & - \\
\hline & \multicolumn{6}{|c|}{ At $\mathrm{pH} 4.0$} \\
\hline Dextrose & $\begin{array}{l}- \\
-\end{array}$ & $\begin{array}{l}0.42 \\
(0.14-0.98)\end{array}$ & $\begin{array}{l}1.12 \\
(0.96-1.9)\end{array}$ & $\begin{array}{l}3.99 \\
(3.2-5.0)\end{array}$ & $\begin{array}{l}15.46 \\
(9.6-20.7)\end{array}$ & $\begin{array}{c}33.29 \\
(17.3-50.4)\end{array}$ \\
\hline Fructose & $\begin{array}{c}0.79 \\
(0.4-1.5)\end{array}$ & $\begin{array}{l}1.60 \\
(1.2-2.2)\end{array}$ & $\begin{array}{l}4.21 \\
(3.7-4.6)\end{array}$ & $\begin{array}{l}14.38 \\
(8.8-18.7)\end{array}$ & $\begin{array}{l}28.06 \\
(16.3-39.4)\end{array}$ & - \\
\hline Dextrose $+0.0625-\mathrm{M}$ Fructose & $\begin{array}{l}- \\
-\end{array}$ & $\begin{array}{l}1.42 \\
(1.2-2.1)\end{array}$ & $\begin{array}{l}2.66 \\
(2.1-3.4)\end{array}$ & $\begin{array}{l}7.61 \\
(5.8-9.8)\end{array}$ & $\begin{array}{l}21.48 \\
(15.9-27.2)\end{array}$ & - \\
\hline \multirow[t]{2}{*}{ Dextrose $+0.125-\mathrm{M}$ Fructose } & $\begin{array}{l}- \\
-\end{array}$ & $\begin{array}{l}2.70 \\
(1.8-3.8)\end{array}$ & $\begin{array}{c}4.68 \\
(4.6-5.2)\end{array}$ & $\begin{array}{l}11.78 \\
(9.2-14.9)\end{array}$ & $\begin{array}{l}24.75 \\
(18.9-32.1)\end{array}$ & - \\
\hline & \multicolumn{6}{|c|}{ At $\mathrm{pH} 2.7$} \\
\hline Dextrose & $\begin{array}{l}- \\
-\end{array}$ & $\begin{array}{l}0.30 \\
(0.19-0.78)\end{array}$ & $\begin{array}{l}0.61 \\
(0.51-1.3)\end{array}$ & $\begin{array}{l}1.98 \\
(1.6-2.3)\end{array}$ & $\begin{array}{l}9.68 \\
(4.2-13.6)\end{array}$ & $\begin{array}{l}18.64 \\
(6.2-23.6)\end{array}$ \\
\hline Fructose & $\begin{array}{l}0.28 \\
(0.09-0.76)\end{array}$ & $\begin{array}{l}0.55 \\
(0.35-1.4)\end{array}$ & $\begin{array}{l}2.27 \\
(1.8-2.7)\end{array}$ & $\begin{array}{l}10.69 \\
(4.4-16.3)\end{array}$ & $\begin{array}{l}18.69 \\
(8.4-25.4)\end{array}$ & - \\
\hline Dextrose $+0.125-\mathrm{M}$ Fructose & - & $\begin{array}{l}1.54 \\
(1.3-2.4)\end{array}$ & $\begin{array}{l}3.08 \\
(2.9-3.9)\end{array}$ & $\begin{array}{l}8.51 \\
(6.49 .9)\end{array}$ & $\begin{array}{l}17.91 \\
(11.9-21.4)\end{array}$ & - \\
\hline
\end{tabular}

$a$ In all experiments the reference, 0.25-M sucrose, was designated as 10 and was served at pH 5.8. Each entry is the geometric mean of 60 responses. Entries in parenthesis are the first and third quartile values.

cited reports (Goudrian, 1930; Tsuzuki \& Kamazaki, 1953) were in disagreement suggesting that the higher temperature would produce both an increase and a decrease in the relative sweetness for a sugar. In the present study, the relative sweetness tended to increase with increasing temperature; however, the differences were quite small and did not approach statistical significance. In fact, we are impressed by the remarkable stability of the responses over this wide temperature range.

At the higher temperature, $50 \mathrm{deg} \mathrm{C}$, we reported a maximum range of $\pm 5 \mathrm{deg}$ which was the exception. In most cases the temperature range was less than $\pm 2 \mathrm{deg}$; however, occasionally this became larger in spite of our efforts so we have reported the maximum values. Observation of the responses for individual Ss did not reveal any inconsistencies in their data when these variations occurred.

The failure to demonstrate a decrease in the relative sweetness of the solutions adjusted to $\mathrm{pH} 4.0$ was unexpected. It is hypothesized that this $\mathrm{pH}$ is not sufficiently acidic and $\mathrm{Ss}$ may have confused this level of sourness with sweetness. Such occurrences have been reported by other investigators (Pangborn, 1961; Pangborn \& Trabue, 1967). Interestingly, Ss commented that the solutions were pleasant and preferred over the test stimuli used in previous experiments.

Recently, Gregson (1968) hypothesized that taste interactions such as the one reported here between the citric acid

Table 4

Summary Statistics-Slope Values, Variances, Standard Deviations, Y-Intercepts, and Correlation Coefficeints (R) for the $\mathrm{pH}$ Experiments

\begin{tabular}{|c|c|c|c|c|c|}
\hline & Slope & Variance & SD & $Y$-intercept & $\mathbf{F}$ \\
\hline & \multicolumn{5}{|c|}{ At $\mathrm{pH} 5.8$} \\
\hline Dextrose & 1.6491 & 0.4576 & 0.6765 & 0.0935 & 0.9745 \\
\hline Fructose & 1.3675 & 0.4120 & 0.6418 & 0.4384 & 0.9684 \\
\hline Dextrose $+0.0625-\mathrm{M}$ Fructose & 1.3642 & 0.1977 & 0.4446 & 0.7183 & 0.9829 \\
\hline \multirow[t]{2}{*}{ Dextrose + 0.125-M Fructose } & 1.2534 & 0.0995 & 0.3155 & 0.7881 & 0.9797 \\
\hline & \multicolumn{5}{|c|}{ At $\mathrm{pH} 4.0$} \\
\hline Dextrose & 1.6374 & 0.4560 & 0.6753 & 0.5838 & 0.9823 \\
\hline Fructose & 1.3453 & 0.2813 & 0.5304 & 0.4770 & 0.9749 \\
\hline Dextrose $+0.0625-\mathrm{M}$ Fructose & 1.3280 & 0.3626 & 0.6022 & 0.2972 & 0.9735 \\
\hline \multirow[t]{2}{*}{ Dextrose $+0.125-\mathrm{M}$ Fructose } & 1.0916 & 0.1273 & 0.3568 & 0.3846 & 0.9795 \\
\hline & \multicolumn{5}{|c|}{ At $\mathrm{pH} 2.7$} \\
\hline Dextrose & 1.5917 & 1.2607 & 1.1228 & -0.1582 & 0.9644 \\
\hline Fructose & 1.6442 & 1.2613 & 1.1231 & 0.3571 & 0.9583 \\
\hline Dextrose $+0.125-\mathrm{M}$ Fructose & 1.2073 & 0.4613 & 0.6792 & 0.2603 & 0.9814 \\
\hline
\end{tabular}


and dextrose-fructose mixtures may be artifacts of the response measure employed by the E. Since our experiments were only concerned with intensity of perceived sweetness, it is not possible to consider whether, in fact, this taste interaction is artifactual or not. It would be most interesting to reconsider these $\mathrm{pH}$ experiments (especially at $\mathrm{pH} 4.0$ ) using methods as described by Gregson (Cases i to v, p. 127).

The fact that the reference always was sucrose did not appear to cause any difficulty on the part of the panel. In our previous study (Stone \& Oliver, 1968) changing the reference or the stimulus tended to shift the Y-intercept but not necessarily the slope of the line.

One additional aspect of this study worth mentioning is the remarkable stability of the synergistic effect described earlier for dextrose-fructose mixtures. The addition of a small amount of the fructose to dextrose produced a mixture sweeter than what one expects from a simple addition of their respective relative sweetness values. Where relative sweetness intensity was depressed, all solutions were affected equally.

\section{REFERENCES}

GOUDRIAN, J. C. Über den Einfluss der temperatur auf die Geschmacksempfindung. Archives néerlandaises de Physiologie de I'homme et des animaux, 1930, 15, 253-282.

GREGSON, R. A. M. Simulating perceived similarities between taste mixtures having mutually interacting components. British Journal of Mathematical \& Statistical Psychology, 1968, 21, 117-130.

PANGBORN, R. M. Taste interrelationships. II. Suprathreshold solutions of sucrose and citric acid. Journal of Food Science, 1961, 26, 648-655.
PANGBORN, R. M. Taste interrelationships of organic acids and selected sugars. In J. M. Leitch (Ed.), Proceedings of the 1st International Congress of Food Science and Technology, London, Vol. III. New York: Gordon and Breach Science Publishers, 1965. Pp. 291-305.

PFAFFMAN, C. The sense of taste. In I. J. Field (Ed.), Handbook of physiology-neurophysiology. Vol. I. Washington D.C.: American Physiological Society, 1959. Pp. 507-533.

SATO, M. Gustatory response as a temperature-dependent process. In W. D. Neff (Ed.), Contributions to sensory physiology. New York: Academic Press, 1967. Pp. 223-251.

STEVENS, S. S. The psychophysics of sensory function. In W. A. Rosenblith (Ed.), Sensory communication. Cambridge: M.I.T. Press, 1961. Pp. 1-33.

STONE, H., \& OLIVER, S. Measu, "ment of the relative sweetness of selected sweeteners and sweet mixtures. Journal of Food Science, 1968 , in press.

TSUZUKI, Y., \& YAMAZAKI, J. The sweetness of fructose and some other sugars. Journal of the Chemical Society of Japan, Pure Chemistry Section, 1953, 74, 596-601.

\section{NOTES}

1. This research was carried out under contract between Stanford Research Institute and Corn Products Company. The authors thank Dr. John Garber of Corn Products Company for his support and encouragement and the panel for their cooperation.

2. Address: Life Sciences Division, Stanford Research Institute, Menlo Park, Calif. 94025

(Accepted for publication November 15, 1968.) 